\title{
THE IMPLEMENTATION OF DIRECTED READING THINKING ACTIVITY (DRTA) IN LITERACY-BASED LANGUAGE TEACHING AT LEMBAGA BIMBINGAN BELAJAR TELADAN KUDUS
}

\author{
Diah Kurniati and Suprihadi \\ UniversitasMuria Kudus
}

\begin{abstract}
For most foreign language learners, understanding texts written in a foreign language is not an easy thing to do. To help learners in coping with this problem, when teaching reading teachers should provide them with a number of structured tasks that not only focus on students' reading purpose, but also allow them to confront and reflect upon reading difficulties in socially interactive ways and one of the activities which is appropriate with these tasks is Directed Reading Activity (DRTA).The objective of the research is to compare the behavior of the English reading classstudents before and after the implementation of DRTA.The subjects of this research were 3 students of $L B B$ TeladanKudus. The conclusion is that the behavior of the students is better than that before the implementation of DRTA. The students become motivated, active, enthusiastic, paid attention to the teaching learning process, and got involved in the teaching learning process. Considering that DRTA has many benefits for learners especially dealing with learners' behaviors, it is suggested that this activity should be used by the teacher when teachingreading.
\end{abstract}

Key words: Riteracy-based Teaching, DRTA, Reading

\section{INRODUCTION}

There are many reasons why getting students to read English texts is an important part of the teacher's job as stated by Harmer (2007). First of all, reading is useful for language acquisition. The more the students read, the better they will get it at. In addition, reading has also a positive effect on students' vocabulary, their spelling, and their writing. Harmer (2007) points out that reading texts also provide good models for English writing. Finally, good reading texts can introduce interesting topics, stimulate ussion, excite imaginative responses, and provide the starting point for well-rounded, fascinating lessons.

Reading is the process of obtaining or constructing meaning from a word or cluster of words (Seyler, 2004). Meanwhile Kern (2000) states that reading is not a matter of extracting fixed meanings from texts, nor it is a matter of making words mean whatever one wants. He argues that texts are always embedded in social and cultural contexts, and only sometimes do these coincide with contexts that are already familiar to foreign language learners. That is way, understanding texts, especially written in a foreign language, is a significant challenge for most students (Kern, 2000), due to the unfamiliar vocabulary, grammar structures, and cultural reference.

The significant challenge of understanding a foreign language text (an English written text) is also faced by Indonesian students, especially the seventh 
grade students of Junior High School who join English class at Lembaga Bimbingan BelajarTeladan (LBB Teladan), a Tutoring Agency which is located at Jepang Village, Mejobo, Kudus. The students who join LBB Teladan come from different schools in Kudus such as SMP 1, SMP 1 Mejobo, SMP 5, and MTS Banat. The practical and common purpose of students enrolling in $L B B$, including in $L B B$ Teladan, is to cope with the learning at their schools, as well as to get enrichment and new experience.

Based on our observation during the teaching learning process, we found that most of the students were not motivated in joining the English lesson, moreover when they discussed reading texts. One of the reasons might be because they did not understand the content of the text. In addition, it might be also because of the teacher's teaching technique. The teacher used conventional technique when teaching reading. He just read the text and asked the students to answer the questions without giving any guidance to the students. In fact, teachers should provide appropriate guidance and support to the students when teaching reading. He/ she should also use certain techniques or activities as well.

The phenomenon of the students' behavior and the lack of appropriate techniques applied at $\angle B B$ Teladan trigger the researchers to implement literacybased language teaching when teaching reading. There are several reading activities in this technique of teaching and one of them is Directed Reading Thinking Activity (DRTA). DRTA is an activitywhich guides students in asking questions about a text, making predictions and then reading to confirm or refute their predictions (Yazdani and Mohhamadi, 2015).

\section{LITERACY-BASED LANGUAGE TEACHING}

According to Kern (2000), "literacy" in a second language means much more than the separate abilities to read and write, but it is a complex concept of familiarity with language and its use in context primarily written extension, but by the extension also spoken texts". Kern argues that literacy covers cultural knowledge and pragmatic and linguistic awareness as well as basic knowledge of lexis and grammatical structure. Literacy in a second language is also promoted through an interaction of reading and writing activities, and through the discussion of language in use in communicative context.

Literacy-based orientation to language teaching does not mean abandoning a communicative focus and reverting back to a grammar translation variety of teaching that emphasizes the analysis and manipulation of language structures. Rather, it means engaging in reading and writing as acts of communication (Kern, 2000). It means sensitizing learners to relationships between language, texts, and social contexts, in order to deepen their understanding of language and culture, and ultimately enhance communicative capacity in human beings.

Related to the teaching reading, because language learners in academic settings ultimately need to learn how to read complex texts, a basic principle of teaching reading in a literacy-based language program is that students need controlled-tasks, not controlled texts. Controlled tasks are a number of structured tasks that not only focus on students' reading purpose, but also allow them to confront and reflect upon reading difficulties in socially interactive ways. In this 
case, the goal in literacy-based teaching is not to present every possible piece of potentially relevant background information, but to allow students to see how the additional background affects their interpretations to see how context influences their particular designing of textual meaning.

It is stated previously, Kern (2000) argues that reading is not a matter of extracting fixed meanings from texts, nor it is a matter of making words mean whatever one wants. Texts are always embedded in social and cultural contexts, and only sometimes do these coincide with contexts that are already familiar to foreign language learners. Therefore, when teaching reading in a foreign language, it should be based on a literacy framework that takes linguistics, cognitive, and sociocultural domain into account. What are the principle things that foreign language students need to learn about reading actually? They need to know that reading is not a generic, all-or-nothing affair (as implied in the classic teacher refrain 'Either you read it or didn't), but rather a process whose particular product is contingent upon a variety of linguistics, cognitive and social factors including culture-specific goals and purposes of reading. Furthermore, Kern (2000) states that in the traditional foreign language curriculum, reading, talking, and writing are relatively distinct phases of a linear instructional sequence. The phases are typically discrete and sequential rather than recursive.

In literacy-based teaching, the relationship between reading, writing, and talking is not linear but overlapping. Reading and writing overlap not only in the sense that students write formal essays about what they have read, but also when they (1) use writing concretely represent their thoughts and interpretations of texts as they read, in the form of reading journals, summaries, or diagrams, (2) write their own version of a topic or theme before reading the target text, in order to be sensitized to the topic or theme before reading commences (3) write reflection on their own reading process, their experiences, difficulties and insight as a component of their report on their independent reading, (4) read to improve their writing when they attend to linguistics, rhetorical, or stylistic elements in texts in order to incorporate them into their own work, and (5) actively and critically read their own and their peers' writing in the editing process.

In the literacy-based teaching, the anticipated goal is not only to enhance skills, but also a greater awareness of language itself, of discourse processes and of literacy practices. To addressthe full range of learners' literacy needs, in organizing activities to achieve these goals, it is useful to refer to 4 curricular components proposed by New London Group, 1996(in Kern, 2000), those are (1) situated practice (in which learners are immersed in written language), (2) over instruction (they receive direct assistance in the complexity of reading L2 texts), (3) critical framing (students learn not just to absorb information but to analyze and evaluate what they read, and (4) transformed practiced (students learn how to reshape or redesign texts through summarization, rewriting or translation.

One useful teaching technique which can be implemented in the situated practice curricular component is Directed Reading Thinking Activity. It is useful for guiding learners' thinking processes during reading and for enhancing their motivation. 


\section{DIRECTED READING TEACHING ACTIVITY (DRTA)}

Directed Reading Thinking Activity is one teaching technique which is useful for guiding learners' thinking processes during reading and for enhancing their motivation. (Kern, 2000). Meanwhile, Yazdani and Mohhamadi (2015) state that DRTA is a strategy that guides students in asking questions about a text, making predictions and then reading to confirm or refute their predictions. Moreover, they argue that DRTA provides teachers an opportunity to guide students to think like good readers do by anticipating, predicting and then confirming, modifying their ideas with the story.

DRTA was developed by Stauffer in 1969. Actually, this guided reading activity can be used at all levels of language teaching. However, it is more useful to be implemented during the early stages when students are developing their ability to process multiple layers of meaning in the new language. DRTA can be profitably used at intermediate and advanced levels in abbreviated forms. In the implementation of this activity, DRTA can encourage readers to do the following things. By using this activity, readers can establish goals and read purposefully. Moreover, they are also able to make inferences and predictions while reading. In addition, DRTA makes readers be able to evaluate the between information in the texts and their own mental representations of the text. In this activity, the teacher's role is to engage learners in cyclical process of predicting, reading and thinking by carefully selecting several stopping points in text and asking two principles questions at each juncture: What do you think is going to happen? Why? (Kern, 2000).

When applying DRTA in literacy-based teaching reading, teachers should follow the following procedures as proposed by Stauffer, 1969(in Kern, 2000).

1. Each student has a copy of the text prepared by the teacher as well as a blank sheet of paper

2. The teacher asks the students to cover all the reading selection except for the first two sentences (alternatively, the teacher can use LCD)

3. The teacher asks the students to read silently (or the teacher can read a loud as they follow silently)

4. After the students read the sentences, the teacher asks a question : Based on what you have just read, what do you think this text will be about? Do you think this will be a story? An essay? A play?

Note: These questions are intended to activate the students' background knowledge related to both the content and the genre of the text

5. In the spirit of open and collaborative expression, the teacher welcomes all the contributions and encourages discussion of all hypotheses

6. In order to maximize participation, the students can be asked to write down their responses before verbalizing them

7. Once several ideas have been offered, the teacher tells the students to move their cover sheet down to the next predetermined point in the selection and read silently to find out whether they were right in their prediction

8. The students are asked to monitor and evaluate what preliminary meanings they have produced so far 
9. When the students have finished reading the segment the teacher then asks the students: What do you think now?

Note: The questions encourage students to assess the appropriateness of their earlier hypotheses and to make any necessary modification

10. After the students have finished reading the segment the teacher then asks: What do you think now or were you right?

11. These questions encourage students to assess the appropriateness of their earlier hypotheses and to make any necessary modification.

12. If the modifications are made, the teacher should follow up by asking: What made you change your mind? In order to focus students' attention on the specific words in the context that made the modification necessary and on the logical and cultural connections the students have just made

13. Before continuing, the teacher asks what will happen next?

14. As the activity continues, the students move their cover sheets to the next stopping point and read the exposed segment silently

15. The student is happy to see her prediction is confirmed by the text. However, again, the teacher follows up her assertion by asking her to clarify exactly what she means

16. The cycle of predicting is repeated until the end of the text is reached ( a total of four or five of stopping point $\mathrm{s}$ is optimal)

17. After briefly discussing the students' reactions, the teacher should ask the students to reread the text without interruption, in order to consolidate their understanding and clarify any unresolved questions.

Other procedures of Directed Reading Thinking Activity were proposed by Billmeyer and Barton (1998) as follows.

1. Students read selection title and subtitle; look at pictures, graphs, and charts, and decide what they know they know about the topic for sure. (What I Know I Know) You could even have them read a small part of the selection if the title is not too informative or indicative of the topic.

2. Next, have students write what they "think" they know about the topic, but aren't sure. (What I Think I Know) Make sure students feel this is risk free. If what they thought they knew is proven wrong, there is no penalty. The bonus is they will definitely remember it now!

3. This is a most important step. Have students predict what they will learn by reading this piece of text. (What I Predict I'll Learn). Have them be specific, but remember they are making a hypothesis. As they read, they will confirm, refine, or reject their initial hypothesis.

4. Have students write down what they have learned. (What I Actually Learned) Have them be specific by writing down actual quotes, facts, and page numbers.

5. This process may be repeated at any point in the text-new chapter, sub-topic, etc.

Considering the activities in the use of DRTA, we can say that DRTA brings cognitive processes into the arena of social interaction. By making learners conscious of their own and others' expectation of a text as well as their 
progressive reconciliation of those expectations to textual facts, DRTA can foster awareness of the communicative nature of reading and writing. In line with this statement, Al Odwan (2012) mentions that another advantage is "the directed reading activity is a much stronger model for building independent readers and learners". Moreover, Blachowicz and Ogle (2002) believe that DRTA is one of the strongest ways which can help teachers engage students actively in the pieces of literature they are reading.

Combining the characteristics of literacy-based English teaching and DRTA, it is interesting to conduct a study on comparing the behavior of the English reading class students of $L B B$ Teladan before and after the implementation of DRTA. Therefore, the objective of this study is to compare the behavior of the English reading class studentsbefore and after the implementation of DRTA.

\section{METHOD}

\section{Design of the Study}

This study belongs to descriptive qualitative research.

\section{Subject of the research}

The subjects of this study were 3 students of the seventh grade enrolling in English class of $L B B$ Teladan.

\section{Data Collection}

The method of collecting the data about the behavior of the English reading class students of $L B B$ Teladanbefore and after the implementation of DRTA was observation. The behavior of the students observed were their attitude and motivation towards the learning process. While doing observation, the researchers took notes of the students' behavior in terms of their motivation, enthusiasm, attention, involvement, and activity.

\section{Data Analysis}

The notes of the students' behavior were calculated in terms of the frequency of appearance. In this way, the dominant behavior could be reported.

\section{Implementing DRTA: the Treatment}

\section{Material}

The reading text used in this study was taken from a first year French class reading a vignette by Alphonse Allais (English version). The consideration of choosing this text was because this text was appropriate for the seventh grade students of Junior High School. The following is the reading text:

(One day I met a poor looking woman holding a four-year old boy by the hand.

The boy was crying.)

(What's wrong with the little one?) 
(He saw a cake as he was passing in front of a pastry shop. But it costs 25 France. I am not rich.....that's why he's fussing it)

(Go buy him his cake, and, and bring me back the change)

(I gave her a 50france bill. Several minutes later, the woman came back with the child,

who was smiling and the change)

(Now everything's fine. Now everyone's happy; the kid because he has his cake, you because your little boy is not crying anymore, the patissier because he sold his cake,

and me because I no longer have my counterfeit bill)

\section{Procedures}

When applying DRTA in literacy based teaching reading, the researchers referred to the procedures as proposed by Stauffer, 1969 (in Kern (2000).

1. Each student has a copy of the text prepared by the teacher as well as a blank sheet of paper

2. The writer asked the students to cover all the reading selection except for the first two sentences

3. The teacher asked the students to read silently and after that the teacher read a loud as they follow silently

4. After the students read the sentences, the writer asked a question : Based on what you have just read, what do you think this text will be about? Do you think this will be a story? An essay? A play?

Note: These questions are intended to activate the students' background knowledge related to both the content and the genre of the text

5. In the spirit of open and collaborative expression, the writer welcomed all the contributions and encourages discussion of all hypotheses

6. In order to maximize participation, the students were asked to write down their responses before verbalizing them

7. Once several ideas have been offered, the writer told the students to move their cover sheet down to the next predetermined point in the selection and read silently to find out whether they were right in their prediction

8. The students were asked to monitor and evaluate what preliminary meanings they have produced so far

9. When the students have finished reading the segment the writer then asked the students: What do you think now?

Note: The questions encourage students to assess the appropriateness of their earlier hypotheses and to make any necessary modification

10. After the students have finished reading the segment the writer then asked: What do you think now or were you right?

11. These questions encouraged students to assess the appropriateness of their earlier hypotheses and to make any necessary modification.

12. When the modifications are made, the writer followed up by asking: What made you change your mind? In order to focus students' attention on the 
specific words in the context that made the modification necessary and on the logical and cultural connections the students have just made

13. Before continuing, the writer asked what will happen next?

14. As the activity continues, the students move their cover sheets to the next stopping point and read the exposed segment silently

15. The student is happy to see her prediction is confirmed by the text. However, again, the teacher follows up her assertion by asking her to clarify exactly what she means

16. The cycle of predicting is repeated until the end of the text is reached ( a total of four or five of stopping point $s$ is optimal)

17. After briefly discussing the students' reactions, the teacher should ask the students to reread the text without interruption, in order to consolidate their understanding and clarify any unresolved questions.

\section{FINDINGS AND DISCUSSION}

\section{The Students' Behaviors before the Implementation of DRTA}

Before conducting this research, the writer did observation on a reading class (a private class) done by the English teacher at $L B B$ Teladan. In the class, after the teacher greeted the students, he directly distributed a reading text and asked the students to answer the questions based on the text. There were 8 questions that should be answered by those students. After 15 minutes the teacher tried to discuss thequestions by asking the student one by one to read aloud their answer. The following table is the summary of the students' behaviorin the reading class before the implementation of DRTA.

Table 1. Students' behaviors before the implementation of DRTA

\begin{tabular}{cl}
\hline No. & \multicolumn{1}{c}{ Students' behavior } \\
\hline 1. & Unmotivated \\
2. & Reluctant \\
3. & Bored \\
4. & did not pay attention on the teaching learningprocess \\
5. & not involved in the teaching learning process \\
\hline
\end{tabular}

\section{The Students' Behaviors after the Implementation of DRTA}

The following week, the researchers taught the students by using DRTA. On that day there were only 3 students attending the class (Nurul, Nico and Kiki). Three students were absent because they had activity at their schools. As it was mentioned earlier, the reading text used in this study was taken from a first year French class reading a vignette by Alphonse Allais (Englishversion).

When applying DRTA in literacy based teaching reading, the researchers referred to the procedures as proposed by Stauffer, 1969 (in Kern (2000). During the implementation of the DRTA, the students were involved in the teaching learning process. The following table is the summary of the students' behaviors in the reading class after the implementation of DRTA. 
Table 2. The students' behavior after the implementation of DRTA

\begin{tabular}{cl}
\hline No. & \multicolumn{1}{c}{ Students' behavior } \\
\hline 1. & Motivated \\
2. & Active \\
3. & Enthusiastic \\
4. & paid attention to the teaching learning process \\
5. & got involved in the teaching learning process \\
\hline
\end{tabular}

\section{CONCLUSION AND SUGGESTION}

Briefly, the conclusion which the researchers can draw after the implementation of DRTA is that the behavior of the students is better than that before the implementation of DRTA. The students become motivated, active, enthusiastic, paid attention to the teaching learning process, and got involved in the teaching learning process. Considering that DRTA has many benefits for learners and can increase the students' motivation and attitude, it is suggested that this activity should be used by the teacher when teaching reading.

\section{REFERENCES}

AL Odwan, T. (2012).The Effect of Directed Reading Thinking Activity Through Cooperative Learning on English Secondary Stage Students' Reading Comprehension in Jordan. International Journal of Humanities and Social Science, 2(16).

Billmeyer, Rachel, and Barton, Mary Lee. (1998). Teaching Reading in the Content Areas: If Not Me,Then Who? McRel, Aurora, Colorado.

Blachowicz, C., \& Ogle, D. (2008).Reading Comprehension Strategies for Independent Learners. New York: The Guilford Press.

Harmer, Jeremy. (2007). How to Teach English. Pearson Education Limited. Edinburg Gate. Harlow, England.

Kern, Richard.(2000). Literacy and Language Teaching.Oxford University Press. New York.

Mehdi Yazdani, Muhammad. (2015). The Explicit Instruction of Reading Strategies : Directed Reading Thinking Activity vs. Guided Reading Strategies. International Journal of Applied Linguistics and English Literature, ISSN 2200-3592 (print), ISSN 2200-3452(Online). Vol.4 No.3; May 2015

Seyler, Dorothy U. (2004). The Reading Context : Developing College Reading Skills. New York :Northem Virginia Community College. 